\title{
Impact Of Arabic Online Learning In The Perspective Of How The Brain Learns
}

\author{
Danial Hilmi \\ UIN Maulana Malik Ibrahim Malang \\ hilmi@pba.uin-malang.ac.id
}

\begin{abstract}
The study aims to describe the impact of learning Arabic online and the viewpoint of brain-based learning on these implications. The research used a mixed-method that combines quantitative and qualitative approaches to get a real picture of the implementation of online learning from a neurolinguistic perspective, the data is obtained through the results of questionnaires and studied in a neurolinguistic perspective based on the literature on the theme. The data collection technique was carried out by distributing questionnaires to PKPBA students who carried out Arabic learning through online and literature review on neurolinguistic studies. The results of this study are that the Arabic learning process carried out online has good benefits with varied but not optimal patterns of interaction through blended learning. In contrast, according to neurolinguistics, it is stated that at least any model can maintain how the potential of the brain through language habituation must be consistent with the balance of the left and right brain.
\end{abstract}

Keywords: Arabic Online; Brain Learns; Neurolinguistic

\begin{abstract}
Abstrak
Tujuan penelitian ini adalah untuk mendeskripsikan implikasi pembelajaran bahasa Arab online dan pandangan pembelajaran berbasis otak terhadap implikasi tersebut. Oleh karena itu, penting untuk lakukan kajian beserta implikasi pembelajaran bahasa Arab yang juga turut mengalami kondisi ini. Metode penelitian yang dilakukan adalah menggunakan mixed method yang menggabungkan pendekatan kuantitatif dan kualitatif untuk mendapatkan gambaran nyata pelaksanaan pembelajaran online menurut perspektik neurolinguistik yang mana data diperoleh melalui hasil penyebaran angket dan dikaji dalam perspektif neurolinguistik berdasarkan literatur tentang tema tersebut. Sedangkan teknik pengumpulan data dilakukan penyebaran angket kepada mahasiswa PKPBA yang melaksanakan pembelajaran bahasa Arab melalui Daring dan kajian literatur tentang studi neurolinguistik. Adapun hasil penelitian ini yaitu bahwa proses pembelajaran bahasa Arab yang dilakukan secara daring yang memiliki manfaat yang baik dengan pola interaksi melalui blended learning yang bervariatif namun belum maksimal, sedangkan menurut neurolinguistik dinyatakan bahwa model apapun setidaknya dapat mempertahankan bagaimana potensi otak melalui pembiasaan berbahasa harus konsisten dengan keseimbangan otak kiri dan kanan.
\end{abstract}

Kata Kunci: Bahasa Arab Online; Otak Belajar; Neurolinguistik 
IJAZ ARAB I

Journal of Arabic Learning

DOI: $10.18860 / \mathrm{ijazarabi.v4i1.10442}$

ISSN(print): $2620-5912$ | ISSN(onIine): $2620-5947$

ejournal.uin-malang.ac.id/index.php/ijazarabi/index/60

\section{INTRODUCTION}

Learning Arabic in essence provides learning opportunities for students to hone their brain's ability to accept and practice the language skills that are being studied. Language development can be practiced in everyday communication in the real world through face to face and practicing the vocabulary and speech patterns learned. Therefore, every student needs to familiarize himself with the conversation forums that require a bridge that develops their potential.

Advances in technology today, encourage students to participate in modernization where current trends are determined by how good they are with information technology. Therefore, self-learning patterns and the availability of all digital information make students no longer struggling with finding knowledge through physical books arranged in libraries still the provision of books, research results, and scientific journals that are available online has made students become individuals who are trying to keep learning from a distance.

The use of distance learning models seems to be an ideal and an idol for developing knowledge they learn by themselves. Therefore, it is not surprising that current students are familiar with many things and master various technologies and even surpass their lecturer's ability because they have studied online or browsed to increase their knowledge.

In the $21^{\text {st }}$ century, education must be able to direct students to live in new situations that arise in themselves and their environment. In such conditions, the ability to learn how to learn (learning how to learn) is needed, this ability can be achieved with the four pillars of education proposed by UNESCO and described as the basics of education (Rusman, 2011: 13).

With learn Arabic, in essence, there are many online media available to assist mastery still the interaction between students and lecturers is less effective which results in the learning process cannot be adequately controlled properly, which requires persistence, patience, and guidance to be able for the skills as well as possible.

The teaching pattern through the interaction between lecturers and students contributes to the empowerment of brain function where brain waves will run rhythmically which does not only maximize one wave, so there is boredom. Therefore, students who learn from online applications only utilize one wave, so according to brain-based learning, this is not optimal for learning, so that the interaction between lecturers and students will encourage the emergence of two or three who will take turns so that boredom can be overcome and learning needs can also be met.

Many studies have examined the use of media to improve education quality, but the media today are insignificant where their use is inadequate and there is no good access to running the media. Therefore, this research leads to how the Arabic learning journey is carried out through Arabic online learning in emergencies so that various patterns and interactions and the latest knowledge have opened the eyes 
IJAZ ARABI

Journal of Arabic Learning

DOI: $10.18860 / \mathrm{ijazarabi.v4i1.10442}$

ISSN(print): $2620-5912$ | ISSN(online): $2620-5947$

ejournal.uin-malang.ac.id/index.php/ijazarabi/index/61

of educators to maximize the use of media which can help solve problems in learning Arabic.

\section{METHOD}

The method used in this research is a mixed method that combines a quantitative approach to find out the real implications of students' perceptions in participating in online learning, and a qualitative approach to find out how the brain's perspective is learning Arabic in online situations.

The data collection technique was carried out by distributing questionnaires with the type of instrument through a google form containing 5 questions covering the implementation of online Arabic learning to students who took online Arabic learning from March to May 2020. Besides a document review was also carried out regarding the concept of online learning from a neurolinguistic perspective to find out whether this learning is relevant or in accordance with the needs of the brain in learning Arabic.

To get comprehensive research, the population of this study is all new students who are required to take Arabic courses at PKPBA. While the sample in this study was 794 randomly from all departments at UIN Maulana Malik Ibrahim Malang, Indonesia. Data analysis used in this study was data analysis through tabulation of questionnaire data, then analyzed qualitatively using data reduction, display, and verification of research results related to completeness of learning Arabic online.

\section{RESULT AND DISCUSSION \\ Impact of Arabic Online Learning}

Learning Arabic as a foreign language in general aims to deliver students in communicating orally and in writing as part of an effort to convey ideas and opinions as well as statements that are born from human thinking processes. Its existence in this world is to become a leader in regulating world order through the ability to think and intelligence in processing words to develop life in the world.

Foreign language learning emphasizes how the communication process can be carried out through teaching and learning situations that require verbal interaction. The pattern of communication between teachers and students through the habituation of foreign languages will provide a gradual increase in mastery. Therefore, the demand to communicate verbally will affect the growth and development of one's skills.

Language is a verbal tool used to communicate and is an arbitrary system of verbal symbols used by a language community to communicate and interact with each other, based on the culture they share (Budianingsih, 2015: 141). Learning Arabic today continues to experience development so that at the time of the Covid19 pandemic that was hitting this country, Arabic learning had to shift its view from being limited to face-to-face learning to distance learning. A learning process like this is not easy to do unless it continues face-to-face through applications that are 


\section{IJAZ ARABI}

Journal of Arabic Learning

DOI: $10.18860 / \mathrm{ijazarabi.v4i1.10442}$

ISSN(print): $2620-5912$ | ISSN(onIine): $2620-5947$

ejournal.uin-malang.ac.id/index.php/ijazarabi/index

relevant to the Blended Learning learning model which is an alternative to learning in the 21 st century.

The life of beings in this world where humans are the central key to population growth and safety should be the starting point for world progress. However, his intelligence sometimes actually leads him to become a creature who acts arbitrarily regardless of the safety of living together. It is human greed and greed that pushes to do unusual things that can even destroy life in this world. Foreign language learning for modern humans is an inevitable necessity where the speed in capturing information will bring it to glory and prosperity in a better life. Therefore, the value of humanity is tested through life in harmony with maintaining goodness and fighting an evil that is done by humans. When viewed in the process of human development, language comes down to make humans progress with the enthusiasm to get to know other people through the process of recognition and scientific study.

Therefore, learning Arabic is also a necessity for all Muslims to know their religion and how to create interactions between humans. Measurable learning can be seen from the percentage of student activity that shows better learning achievement, it must be determined what percentage of students take Arabic language learning, which in essence will increase learning outcomes. Meanwhile, the following are the results of distributing questionnaires to students in taking online lectures:

Table 1. Student Attendance in Online Lectures

\begin{tabular}{c|c|c}
\hline Number & Student Attendance & Percentage \\
\hline 1 & Always Present & $30 \%$ \\
\hline 2 & Attend Frequently & $44,7 \%$ \\
\hline 3 & Occasionally Present & $18,8 \%$ \\
\hline 4 & Rarely Attend & $5,8 \%$ \\
\hline 5 & Never Present & $0,7 \%$ \\
\hline
\end{tabular}

Based on the table above, information can be obtained that in essence the level of participation in learning Arabic online is going very well with a composition of around $30 \%$ of students always actively attending lectures and $44.7 \%$ of students claiming to be active in taking Arabic courses through various agreed applications.

Learning online in Arabic courses is generally seen as more participatory than coming to class to be physically present so that a strong desire to attend can be replaced through the use of information media which is essentially more attractive to students. Today's learning also has to face challenges where the temptation of using cellphones or gadgets often accompanies the learning process in the classroom. Thus, if students have to learn through applications or modern media, they are better prepared to be active and present in the virtual world.

In contrast to face-to-face learning in a class, the level of student attendance is virtually more active than physically present, this is because the activeness experienced directly will have a big impact where courage will be the main asset, 


\section{IJAZ ARABI}

Journal of Arabic Learning

DOI: $10.18860 / \mathrm{ijazarabi.v4i1.10442}$

ISSN(print): $2620-5912$ | ISSN(onIine): $2620-5947$

ejournal.uin-malang.ac.id/index.php/ijazarabi/index/63

while virtual learning does not require courage because face to face not done physically, which could be when something goes wrong, there are many ways to avoid it, such as disabling the camera or microphone.

Sometimes there are signal constraints that affect participation in learning Arabic so that students have to hold back any questions to be asked. Besides that, the limited quota also affects the fluency of learning Arabic, then students turn off the camera so they don't consume more quota so that they are not free to express themselves in explaining the material, conveying tasks physically. and even improve student understanding.

Sometimes in the Arabic learning process, there is a virtual stigma that online learning is carried out through face-to-face or blended learning which mixes faceto-face learning with distance learning and the form of assignments that are carried out purely such as distance learning which is carried out in their respective homes with virtually eliminating face to face. The following is the result of a questionnaire about student perceptions of the implementation of Arabic learning through virtual face-to-face:

Table 2. Student Perceptions of Online Learning

\begin{tabular}{c|c|c}
\hline Number & Student Perceptions & Percentage \\
\hline 1 & Very Fulfilling Online Learning & $9,4 \%$ \\
\hline 2 & Meet Online Learning & $35,6 \%$ \\
\hline 3 & Enough to Meet Online Learning & $32,5 \%$ \\
\hline 4 & Less Fulfilling Online Learning & $17,3 \%$ \\
\hline 5 & Doesn't meet Online Learning & $5,2 \%$ \\
\hline
\end{tabular}

Based on the information above, it is obtained information that Arabic learning is following the distance learning process, this is based on the fact that the learning process is face-to-face using interactive learning applications. As the results of the questionnaire distribution show that $9.4 \%$ strongly agree that lectures that are experienced are perfect for conducting long-distance lectures, $35.6 \%$ agree that lectures are in the form of face-to-face distance, $32.5 \%$ are neutral in the form of face-to-face long-distance lectures, $17.3 \%$ disagree Long-distance face-to-face lectures and $5.2 \%$ disagreed with face-to-face lectures.

The most dominant percentage is at the upper level, namely the level of agreement which states that the lectures that have been running are interaction in the form of face-to-face distance. This indicates that learning Arabic through Online is well implemented and not only through assignments that are morally ineffective for learning Arabic. Online Arabic learning should form language habituation by enabling more students to communicate so that not only assignments are carried out that do not provide effective language experience.

Some students admit that learning is more of an assignment in nature so that it is generally less effective for improving Arabic language skills. Based on this, it is necessary to further rearrange distance learning which is presented interactively which involves face-to-face processes that can develop language competencies. This is very possible considering the level of student attendance through online 


\section{IJAZ ARABI}

Journal of Arabic Learning

DOI: $10.18860 / \mathrm{ijazarabi.v4i1.10442}$

ISSN(print): $2620-5912$ | ISSN(online): $2620-5947$

ejournal.uin-malang.ac.id/index.php/ijazarabi/index/64

learning is more active than class attendance because the use of technology is more popular and easier to follow.

In regular Arabic learning, effectiveness is sometimes determined by the quantity of attending lectures so that the material can massively be followed even though other factors influence such as lecturer methods in teaching, material that is deemed less appropriate to the student context, and the ability of students to absorb and apply language learning Arab. However, in the process of learning Arabic online, the quantity of taking part in learning is not always in line with the quality of material absorption, this is due to limitations that occur in the interaction between the two parties to develop their abilities. Meanwhile, there are the results of distributing questionnaires about the benefits of learning Arabic online for students: Table 3. Student Views on the Impact of Online Learning

\begin{tabular}{c|c|c}
\hline Number & Impact of Online Learning & Percentage \\
\hline 1 & Very Helpful & $7,4 \%$ \\
\hline 2 & Helpful & $34,3 \%$ \\
\hline 3 & Quite Useful & $38,5 \%$ \\
\hline 4 & Less Useful & $15,5 \%$ \\
\hline 5 & Useless & $4,3 \%$ \\
\hline
\end{tabular}

Arabic learning has the advantage of being taught through distance learning, this is because technology media that are more desirable by students can be channeled in any learning process coupled with the ease of accessing all information quickly and efficiently. The presentation of several applications will be very helpful for increasing language mastery which of course must be guided and guided by the teacher, so face-to-face interactions absolutely must be done by minimizing assignments unless they are enrichment that supports language skills.

Based on the results of distributing questionnaires, it was stated that $7.4 \%$ of distance learning was very useful, $34.3 \%$ useful, $38.5 \%$ quite useful, $15.5 \%$ less useful and $4.3 \%$ not useful. The information above indicates that the distance learning process is beneficial for improving students' Arabic language skills, which is shown by more than a third of respondents, while more than a third stated that it is quite useful which means there is a slight increase but is constrained by other things that interfere with the learning process. Then there is one-fifth of the respondents who stated that learning increasing Arabic language skills which of course could be due to the smooth learning process, the assignment system given by the teacher, or the motivation to learn that came from oneself.

Regarding the impact of learning Arabic online, perceptions can be seen and felt by students themselves. Online lectures cannot see progress directly except for the activeness of teachers in monitoring developments in the form of student responses in doing tasks that are limited online. Therefore, real benefits can be seen when students can take advantage of several sites that can help improve their learning by browsing the internet to hone their skills. As the results of distributing questionnaires about students' abilities in Arabic language skills: 


\section{IJAZ ARABI}

Journal of Arabic Learning

DOI: $10.18860 / \mathrm{ijazarabi.v4i1.10442}$

ISSN(print): $2620-5912$ | ISSN(online): $2620-5947$

ejournal.uin-malang.ac.id/index.php/ijazarabi/index/65

Table 4. Student Ability in the Online Learning Process

\begin{tabular}{c|c|c}
\hline Number & Ability & Percentage \\
\hline 1 & Very Good & $4 \%$ \\
\hline 2 & Good & $22,3 \%$ \\
\hline 3 & Fairly Good & $38,8 \%$ \\
\hline 4 & Less Good & $26,6 \%$ \\
\hline 5 & Not Good & $8,3 \%$ \\
\hline
\end{tabular}

learning Arabic requires direct interaction to be able to equip and practice what they learn in the classroom. At the same time, the instructor will provide guidance and tutorials on how to demonstrate language skills directly which are needed practical conversation habituation to form speaking skills.

This is comparable to the distance learning process that has been running for two months during the Covid-19 pandemic where Arabic learning is also carried out online which reduces physical face-to-face. The results of the distribution of the questionnaires were as follows: $4 \%$ of students felt that their Arabic language skills were very good, $22.3 \%$ of students felt that their Arabic skills were good, $38.8 \%$ of students felt that their Arabic skills were sufficient, 26.6\% of students felt that their Arabic skills were lacking good, and $8.3 \%$ of students felt that their Arabic language skills were not good.

Based on this information, it is stated that less than a third of students have good Arabic language skills, which cannot be ascertained whether they have abilities before or whether they already have good abilities. More than a third of students felt that their language skills were at a moderate level after attending lectures, while a third of students felt that their Arabic skills had not improved. In practice, pure learning is carried out in an assignment so that the process of increasing competence is not given attention.

Increasing Arabic language skills is usually followed by student participation to encourage their enthusiasm for learning through other media. This can be seen in students who have a high desire to make more use of technology in building concepts and applying them to hone their Arabic language skills. The following are students' perceptions in honing their abilities as a follow-up to the online learning process:

Table 5. Inspirational Level Honing Arabic Language Skills

\begin{tabular}{c|c|c}
\hline Number & Inspiring Level & Percentage \\
\hline 1 & Very Inspiring & $5 \%$ \\
\hline 2 & Inspiring & $25,7 \%$ \\
\hline 3 & Quite Inspiring & $40,8 \%$ \\
\hline 4 & Less Inspiring & $22,3 \%$ \\
\hline 5 & Doesn't Inspire & $6,2 \%$ \\
\hline
\end{tabular}

The real form of the implications of the implementation of foreign language learning is students' hobby of honing their ability to continue to develop independently or in groups to build mutual competence. One form of this hobby is 
Journal of Arabic Learning

DOI: $10.18860 / \mathrm{ijazarabi.v4i1.10442}$

ISSN(print): $2620-5912$ | ISSN(online): $2620-5947$

ejournal.uin-malang.ac.id/index.php/ijazarabi/index/66

being happy to read foreign language texts, accessing foreign language videos, or attending seminars or meetings where teaching a foreign language can foster enthusiasm for learning faster.

Based on the results of distributing questionnaires to students, it was found that follow-up data after participating in Arabic learning through distance learning were as follows: $5 \%$ of students felt it was very important to hone their Arabic language skills through various means that could be followed, $25.7 \%$ of students felt important, 40, 8\% feel sufficient or neutral in taking a stance to develop themselves, $22.3 \%$ feel it is not important to hone their Arabic language skills and $6.2 \%$ feel it is not important to hone their Arabic language skills.

The explanation above explains that learning Arabic Online is not significant for smoothing Arabic language skills with the impact that they are not ready to attend seminars or read Arabic books. This condition is possible for those who study in the field of language or Islam which is needed. While more than a third do not take a neutral stand with the need to develop their language, which may arise from the existence of the field they are involved in, sometimes it is needed but not directly to do now.

Likewise, less than a third of respondents felt it was not important to hone their Arabic language skills through various meetings or reading Arabic books. This may be experienced by students who study in the general field and are less motivated to learn Arabic, especially since there is no urgency for them to hone their language skills.

\section{A Neurolinguistic Review of The Implications of Arabic Online Learning}

The implementation of Arabic learning in the last period illustrates how much technological mastery is needed, especially in effective and efficient learning by continuing to carry out online learning without reducing the quality of learning. This condition requires mastery of technology that must be owned by all parties by implementing digital language learning.

If previously the media was only seen as a means of support, then in a pandemic situation, technology-based learning media would be needed which would be a primary need in using it. Also delivery through technology is not the same as face-to-face delivery in class so that the aspects of optimizing learning must be carefully and dynamically considered. Blended Learning has been popular in language learning and teaching methodology since this digital era enables both students and teachers to access online sources easily (Isti'anah, 2017: 17; Hilmi, 2020).

Blended learning that is applied to Arabic learning in a madrasah, is a combination of face-to-face learning and distance learning between teachers and students, where the teacher assigns students to use technology and information media (Hayati, 2018: 2). The implementation of blended learning is trying to maintain a face-to-face system between educators and students that are carried out 


\section{IJAZ ARAB I}

Journal of Arabic Learning

DOI: $10.18860 / \mathrm{ijazarabi.v4i1.10442}$

ISSN(print): $2620-5912$ | ISSN(online): $2620-5947$

ejournal.uin-malang.ac.id/index.php/ijazarabi/index

over a distance so that the Arabic learning process does not decrease in significance which requires direct interaction.

A very important and fundamental element in all interactions is the skill to understand what the other person/speaker is saying/saying. Many of the listeners we meet are less skilled in daily language life, both in mother tongue and in the second language, most adults have spent time in communication activities, because of lack of focus, egocentrism, or because of the short nature of memories through hearing (Iskandarwassid, 2009: 229). Situation model building ability was found to predict reading comprehension over and above the other cognitive and linguistic predictors to the same extent in both groups (Raudszus, 2019; Burgoyne et al, 2013; Kieffer, 2012),

Through the application prepared by the teacher, it will provide a measurable gap in the implementation of learning which is always related to improving listening skills (istima'), speaking (kalam), reading (qira'ah) and writing (kitabah) which is supported by mastery of language elements include sound (ashwat), vocabulary (mufrodat) and structure (tarkib). Skills and mastery of these language elements will not be realized unless there is intensive mentoring, like the assistance in reading the al-Qur'an which must be done in front of the teacher directly. Blended learning, in this case, provides facilities for learning Arabic face-to-face but it is carried out remotely by of course involving relevant technology to provide sufficient space for interaction between various parties.

Blended learning was originally used to describe subjects that tried to combine face-to-face learning with online learning. Apart from blended learning, other terms are often used, including blended learning and hybrid learning. The terms mentioned earlier contain the same meaning, namely combination, mixing, or a combination of learning (Sjukur, 2012: 370).

The Arabic learning process lately requires adequate creations to give a good impression in producing quality Arabic learning that is relevant to modern needs. Meanwhile, blended learning as a solution to learning Arabic in today's era needs to find a place where the Covid-19 pandemic situation requires all elements to carry out learning from their respective domiciles.

Arabic learning should pay attention to how the brain learns, especially the balance between the left and right brain because both have complementary advantages. According to Muhammad (2010) that someone who has a dominant left brain, is more selfish and a bit arrogant because they always follow the rules. While the dominant right brain, it will be easy to associate and expertise in creativity that can become emotions.

The dominance of a certain brain will provide experiences to students' growth and development in certain fields where the left brain does more rational things, while the right brain is more concerned with imagination and better creation. Therefore, a teacher must facilitate how the student's brain develops according to their nature and potential. 
The ability of a teacher in language does not guarantee that he is skilled in teaching the language. An Arabic teacher should have at least three skills, namely: 1) proficiency in Arabic, 2) knowledge of Arabic language and culture, and 3) Arabic teaching skills (al- 'Ushaili, $1423 \mathrm{H}$ : 268). The teachers, syllabus, and course designers have to put efforts to design and develop attractive and innovative course materials (Aladdin, 2007). In this regard, the use of information and communication technology must be mastered by an Arabic teacher, this is inseparable from the role and function of media intended for distance learning as currently implemented.

Learning through distance learning, which is not carried out in a classroom situation, requires adequate means of connecting communication and the process of delivering material so that it is possible to practice mastering Arabic language skills. In the meantime, proficiency in technology is also an important concern to provide an interesting experience through the media used but does not reduce the effectiveness of learning Arabic as a whole.

The real impact of the use of technology, especially the implementation of online learning, will change all settings and there is a lack of optimal supervision to monitor the development of student languages. Therefore, assistance in how the brain learns must also be nurtured in such a way so that optimal learning outcomes are obtained.

Meanwhile, Ohlsen (2006; Muhammad, 2010) argues that neurolinguistics essentially examines the relationship between language and communication in other aspects of brain function, in other words exploring brain processes for language production and communication. This study involves an attempt to combine neurological/ neurophysiological theory (brain structure and function) with linguistic theory (language structure and function). The students sometimes demonstrate that this learning involves assimilation into the same reading network that supports native literacy, as evidenced by learning-related changes in orthographic, phonological, and semantic regions associated with Arabic word reading. Additionally, we found learning patterns that varied across the two orthographies. Faceabary induced bilateral learning effects in the mid-fusiform gyrus and showed greater engagement of regions associated with semantic processing (Martin, 2019: 120).

Viewed from the neurolinguistic aspect, the impact of online learning must be able to carry out communication while maintaining a functioning brain rhythm. The language structure possessed by students should be carried out as much as possible through language habituation and exploring with a balance between the left and right brains to maintain their memory.

The neurolinguistic principle says that the optimization of the level of human language is influenced by how strong the quality and quantity of human nerves in transferring and processing the information that has been obtained. If the information is considered to have no meaning in the life of students, then the information will not last long in the nerves (Hilmi, 2017: 136). 
The memory of knowing Arabic vocabulary depends on how the nerves of the brain run or have good connections, so the right formula is needed to build these connections through the learning stages. Online learning that is built with an assignment system will not be able to carry out the role of language, which incidentally must be familiarized and assisted. The implication that leads to less optimal learning is due to ineffective learning to hone students' Arabic language skills.

This tendency is also influenced by how the Arabic language learning habit is given a greater portion of honing their Arabic language skills. Therefore, motivation is very important to form brain nerves that are in line with learning expectations, especially in the acquisition of optimal language with flexibility and flexibility in memorizing and practicing. However, after puberty, this flexibility will decrease and the achievement is not optimal (Field, 2003: 84; Hamizul, 2015). Thus, online learning must also pay attention to how the stimulus can continue and how learning can generate brain performance. The principle of meaning will also encourage maintaining the stability of the information flow that is owned.

To give a more interesting and optimal impression in the Arabic learning process, educators need to provide a stimulus for the continuity of blended learning by paying attention to how the brain learns. The formation of the brain in learning Arabic can be obtained by knowing neurolinguistics to carry relevant messages. Neurolinguistics is a branch of macro linguistics that studies the anatomy of the brain nerves about language. Meanwhile, pragmatically there is a close relationship between the meaning of language and the anatomy of the brain which greatly influences the learning process. It is this continuity between the brain and language, so experts develop linguistics into a new branch called neurolinguistics (Amin, 2016: 62; Ingram, 2007: 3; Fernandez \& Cairns, 2011: 81; Fromkin, 2003: 37).

Students generally confused the meanings of other characters that shared the semantic radical. The study shows that in the initial stage of learning, overlapping information of the shared radicals is effectively learned. The acquisition of the specifics of individual characters, however, requires more training (Takashima, 2019; Yang, 2006; Ding, 2004; Anderson, 2003; Liu, 2017; Mc Bride, 2003).

In learning Arabic based on neurolinguistics, it prioritizes how to emphasize the learning process through activities that can support the optimization of the brain in processing and utilizing thoughts that can have a positive effect in each stage of learning. Likewise in the use of technology, it should also consider how the brain learns to receive material and transforms it in the form of linguistic expressions which is carried out in the form of effective communication habituation.

The development of advances in Information and Communication Technology today is taking place so rapidly. Even though this progress is still on its way, from now on it can be predicted that there will be various changes in the information sector and other related areas of life, as an implication of the development of this situation (Rusman, 2011: 239; Tajuddin, 2019). 


\section{IJAZ ARABI}

Journal of Arabic Learning

DOI: $10.18860 / \mathrm{ijazarabi.v4i1.10442}$

ISSN(print): $2620-5912$ | ISSN(online): $2620-5947$

ejournal.uin-malang.ac.id/index.php/ijazarabi/index/

Optimal use of learning technology, at least still pays attention to how the brain can learn well. So in this case there are three techniques in building a learning process that optimizes brain performance, namely pacing-leading, matching, and mirroring. In NLP Pacing can be interpreted as equalizing or harmonizing, the step of equating the world model that is owned by others as conveyed by Widodo (2008) in Sailendra (2014: 71).

Technology in the 21 st century demands a learning process including Arabic learning to take advantage of media that are relevant and in line with the times. Meanwhile, students are currently more active and active in operating their smartphones in every personal and social activity. Therefore, the world of students in the $21^{\text {st }}$ century tends to use technology-based learning processes that all educators must know to be able to process learning based on the conditions of their students. Harahap (2019) said that the use of technology such as the internet in improving educational achievement has increased rapidly.

The tendency to carry out Arabic learning online, will not automatically provide effective learning outcomes. This is because the role of the lecturer is very influential on how to stimulate language habituation in which the brain requires habituation to be able to hone students' language skills through the left brain and add creativity and idea development through the right brain in the aspects of creativity and imagination.

\section{CONCLUSION}

Learning Arabic online is a custom that must be done considering that the pandemic situation demands changes in interaction patterns in carrying out the teaching and learning process. Based on the research results, it was found that students were seen as more active in participating in the Arabic learning process from the aspect of attendance, but the resulting implications were still some students who experienced an increase because the role of lecturers was needed to provide space and opportunities for students to be more active by utilizing the available platforms for practice his language skills.

Meanwhile, neurolinguistics holds that the human brain with language requires dominant habituation in which the balance of the left and right brain is a determinant of the success of Arabic proficiency. Therefore, Arabic language lecturers through the available platforms must pay attention to the progress of student language learning with more Arabic practice through language project assignments to familiarize their language skills.

\section{REFERENCES}

Ahlsen, Elizabeth. (2006). Introduction to Neurolinguistics. Amsterdam: John Benjamin Publishing Company

Aladdin, A. (2016). A Needs Analysis for the Course Materials Design of the Arabic Language Course. International Journal of Social Science and Humanity, 6 (6), 423-426. https://dx.doi.org/10.7763/IJSSH.2016.V6.684 
IJAZ ARAB I

Journal of Arabic Learning

DOI: $10.18860 / \mathrm{ijazarabi.v4i1.10442}$

ISSN(print): $2620-5912$ | ISSN(online): $2620-5947$

ejournal.uin-malang.ac.id/index.php/ijazarabi/index/71

Al-'Ushaili, Abdul 'Aziz Ibrahim. (1423 H) Asasiyat Ta'lim al-Lughah al'Arabiyyah Li an-Nathiqin bi Lughat Ukhra. Riyadh: Jami'ah al-Imam Muhammad bin Su'ud al-Islamiyah

Amin, Taqwa Nur. (2016). Keutamaan Teknik Pendekatan Neurolinguistic Programming Dalam Proses Pembelajaran (Sebuah Konsep Strategi Pembelajaran Bahasa Arab Bagi Mahasiswa Belajar Pemula). Jurnal Nady Adab. Vol 12 (1) Februari 2016, 61 - 74

Anderson, R. C., Li, W., Ku, Y.-M., Shu, H., \& Wu, N. (2003). Use of Partial Information in Learning to Read Chinese Characters. Journal of Educational Psychology, 95(1), 52-57. http://dx.doi.org/10.1037/0022-0663.95.1.52

Budianingsih, Tri. (2015). Peran Neurolinguistik dalam Pengajaran Bahasa. Jurnal al-Azhar Indonesia Seri Humaniora. Vol 3 (2) September 2015, 137 - 149

Burgoyne, K., Whiteley, H. E., \& Hutchinson, J. M. (2013). The Role of Background Knowledge in Text Comprehension for Children Learning English As an Additional Language. Journal of Research in Reading, 36, 132-148. https://doi.org/10.1111/j.1467-9817.2011.01493.x.

Ding, G., Peng, D., \& Taft, M. (2004). The Nature of the Mental Representation of Radicals in Chinese: A Priming Study. Journal of Experimental Psychology: Learning, Memory, and Cognition, 30(2), 530-539

Fernandez, Eva M and Helen Smith Cairns. (2011). Fundamentals of Psycholinguistics. Wiley: Blackwell Publishing

Field, John. (2003). Psycholinguistics: A Resource Book for Students. New York: Routledge.

Fromkin, Victoria; Robert Rodman and Nina Hyams. (2003). An Introduction to Language 7th edition. Boston: Thomson Wadsworth

Hamizul, M. \& N. M. Rahimi (2015). Design and Development of Arabic Online Games - A Conceptual Paper. Procedia - Social and Behavioral Sciences, 174, 2015, 1428-1433. https://doi.org/10.1016/J.SBSPRO.2015.01.771

Harahap, F. et al. (2019). The Effect of Blended Learning on Student's Learning Achievement and Science Process Skills in Plant Tissue Culture Course. International Journal of Instruction, 12 (1), 521 - 538. https://doi.org/10.29333/iji.2019.12134a

Hayati, Nur dan Muallim Wijaya. (2018). Pengelolaan Pembelajaran Melalui Blended Learning Dalam Meningkatkan Receptive Skill Peserta Didik di Pondok Pesantren. Palapa: Jurnal Studi Keislaman dan Ilmu Pendidikan. Vol. $6(2)$

Hilmi, Danial. (2017). Sistem Pembelajaran al-Qawa'id al-Sharfiyah di Indonesia Ditinjau Dalam Perspektif Neurolinguistik. Jurnal Tarbiyatuna. Vol. 2 (1)

Hilmi, Danial \& Ifawati, Nur Ila. (2020). Using the Blended Learning as an Alternative Model of Arabic Language Learning in the Pandemic Era. Arabi: Journal of Arabic Studies, 5 (2)

Ingram, John CL. (2007). Neurolinguistics: An Introduction to Spoken Language Processing and Its Disorders. Cambridge: Cambridge University Press 


\section{IJAZ ARAB I}

Journal of Arabic Learning

DOI: $10.18860 / \mathrm{ijazarabi.v4i1.10442}$

ISSN(print): 2620-5912 | ISSN(onIine): 2620-5947

ejournal.uin-malang.ac.id/index.php/ijazarabi/index/ 72

Iskandarwassid. (2009). Strategi Pembelajaran Bahasa. (Bandung: PT Remaja Rosdakarya).

Isti'anah, Arina. (2017). The Effect of Blended Learning on the Student's Achievement in Grammar Class. Indonesian Journal of English Education, 4 (1), 16 - 30, https://dx.doi.org/10.15408/ijee.v4i1.5697

Kieffer, M. J. (2012). Early oral language and later reading development in Spanish-speaking English language learners: Evidence from a nine-year longitudinal study. Journal of Applied Developmental Psychology, 33, 146157. https://doi.org/10.1016/j.appdev.2012.02.003

Liu, D., Li, H., \& Wong, K. S. R. (2017). The Anatomy of the Role of Morphological Awareness in Chinese Character Learning: The Mediation of Vocabulary and Semantic Radical Knowledge and the Moderation of Morpheme Family Size. Scientific Studies of Reading, 21(3), 210-224. http://dx.doi.org/10.1080/10888438.2017.1278764

Martin, Lea. et al. (2019). Do adults acquire a second orthography using their native reading network?. Journal of Neurolinguistics, 50 (4), 120 - 135, https://doi.org/10.1016/j.jneuroling.2018.03.004

McBride-Chang, C., Shu, H., Zhou, A., Wat, C. P., \& Wagner, R. K. (2003). Morphological Awareness Uniquely Predicts Young Children's Chinese Character Recognition. Journal of Educational Psychology, 95(4), 743-751. http://dx.doi.org/10.1037/0022-0663.95.4.743

Muhammad, As'adi. (2010). Bila Otak Kanan dan Otak Kiri Seimbang. Jogjakarta: Diva Press. Cet. I

Raudszus, Henriette. Eliane Segers and Ludo Verhoeven. (2019). Situation model building ability uniquely predicts first and second language reading comprehension. Journal of Neurolinguistics, 50 (11), 106 - 119, https://doi.org/10.1016/j.jneuroling.2018.11.003

Rusman, Dedi kurniawan, dan Cepi Riyana. (2011). Pembelajaran Berbasis Teknologi Informasi dan Komunikasi: Mengembangkan Profesionalitas Guru. Jakarta: PT. Raja Grafindo Persada.

Sailendra, Annie. (2014). Neuro-Linguistic Programming (NLP). Yogyakarta: Bhafana Publishing. Cet.II.

Sjukur, Sulihin B. (2012). Pengaruh Blended Learning Terhadap Motivasi Belajar dan Hasil Belajar Siswa di Tingkat SMK. Jurnal Pendidikan Vokasi. Vol 2 (3)

Tajuddin, Shafruddin; Kamal, Muhammad and Zuryati. (2019). Arabic Material Development Design for Senior High School. Arabiyat: Jurnal Pendidikan Bahasa Arab dan Kebahasaaraban, 6 (1), 93-107. http://dx.doi.org/10.15408/a.v6i1.10949

Takashima, Atsuko \& Ludo Verhoeven. (2019). Radical Repetition Effects in Beginning Learners of Chinese as a Foreign Language Reading. Journal of $\begin{array}{llll}\text { Neurolinguistics } & 50 & \text { (3), }\end{array}$ https://doi.org/10.1016/j.jneuroling.2018.03.001 
IJAZ ARABI

Journal of Arabic Learning

DOI: $10.18860 / \mathrm{ijazarabi.v4i1.10442}$

ISSN(print): $2620-5912$ | ISSN(online): $2620-5947$

ejournal.uin-malang.ac.id/index.php/ijazarabi/index/73

Yang, J., Zevin, J. D., Shu, H., McCandliss, B. D., \& Li, P. (2006). A “Triangle Model" of Chinese Reading. Paper Presented at the 28th Annual Conference of the Cognitive Science Society, Mahwah, NJ 